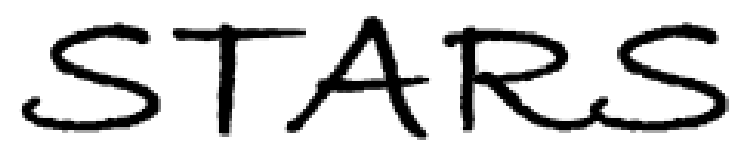

University of Central Florida

STARS

$1-1-2013$

\title{
\#VirtualTourist: Embracing Our Audience through Public History Web Experience
}

Anne Lindsay

University of Central Florida

Find similar works at: https://stars.library.ucf.edu/facultybib2010 University of Central Florida Libraries http://library.ucf.edu

This Article is brought to you for free and open access by the Faculty Bibliography at STARS. It has been accepted for inclusion in Faculty Bibliography 2010 s by an authorized administrator of STARS. For more information, please contact STARS@ucf.edu.

\section{Recommended Citation}

Lindsay, Anne, "\#VirtualTourist: Embracing Our Audience through Public History Web Experience" (2013). Faculty Bibliography 2010s. 4315.

https://stars.library.ucf.edu/facultybib2010/4315

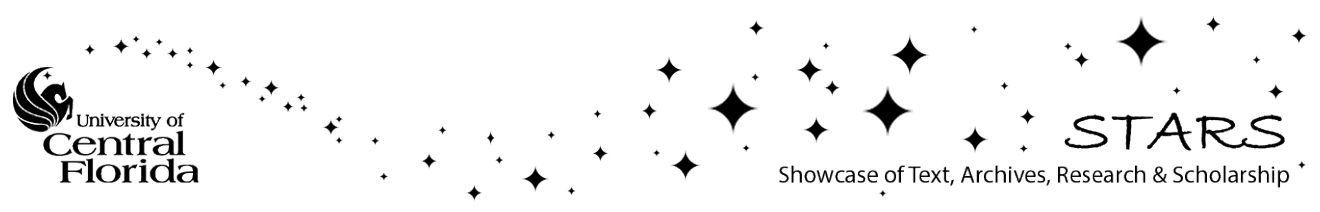




\title{
Possibilities of Digital History
}

\section{\#VirtualTourist: Embracing Our Audience through Public History Web Experience}

\author{
ANNE LINDSAY
}

\begin{abstract}
Public historians at sites of cultural heritage tourism struggle to engage with an ever-changing audience. The solution proposed in this work is the cultivation of the virtual community as a valuable audience and future donor base. Through an analysis of the web presence and social media activities of three high profile heritage locations in Virginia, Mount Vernon, Monticello, and Colonial Williamsburg, it is possible to devise best practices for interaction with the virtual tourist. These principles can be implemented at any site, large or small, and seek to create an immersive educational experience to be enjoyed by guests of many ages and interests. The key consideration must be to court the virtual visitor as a new and valuable audience essential to the continuation of perceived relevance at heritage locations across the country.
\end{abstract}

Key words: cultural heritage tourism, social media, web presence, public history, virtual tourist

JANE IS A HERITAGE TOURIST. She is always looking for a good experience, an opportunity to expand her learning and to interact with the past. A perusal of her Netflix queue and her Facebook "Likes" confirm that she has an interest in all things historical with American history as a favorite. When a work colleague came back from vacation and recommended Monticello, home of Thomas Jefferson, Jane decided that it was time for a visit. Her tour was everything she hoped. She was able to listen to a knowledgeable docent

The Public Historian, Vol. 35, No. 1, pp. 67-86 (February 2013). ISSN: 0272-3433, electronic ISSN 1533-8576.

(C) 2013 by The Regents of the University of California and the

National Council on Public History. All rights reserved.

Please direct all requests for permission to photocopy or reproduce article content through the University of California Press's Rights and Permissions Web site: www.ucpressjournals.com/reprintInfo.asp. DOI: 10/1525/tph.2013.35.1.67. 
who engaged with not only the history of the residence, its architecture and planning, but with the history of Jefferson himself, as a man beyond his political persona. She took in the entrance hall with its eclectic mix of marble busts, maps, Native American artifacts, and the Seven Day Clock and understood that Jefferson was a complicated man with many interests, so much more than a founder and political figure. In the Book Room and Book Room Annex, Jane, a great lover of books, squinted to see the titles, hoping that she and Jefferson might share some reading interests. In the Dome Room, Jane imagined later generations of the Jefferson family playing and living in this space. When the tour was complete Jane agreed with her colleagueMonticello was worth the visit. She especially appreciated the podcast on the restoration of the Dome Room on the third floor of the residence and the additional "Domestic Life" tour she took of the book room, supplemental information on two of her favorite spaces, one of the perks of conducting her visit to Monticello online. ${ }^{1}$

Jane is an avid virtual tourist. Her income does not allow her travel and visit historic museums and residences in person as much as she would like. However, the depth of content available online with some institutions allows her to have the tourist experience from her living room or the café where she has lunch. When she does have the funds to travel, the locations that she has visited online will be at the top of her list. When she thinks about charitable giving or purchasing unique gifts for loved ones these are her go-to locations. Even without stepping foot on the grounds Jane has developed a relationship with these institutions that will continue to be enriching for all parties involved.

What is a virtual tourist? It is a person who seeks the experience of tourism through a virtual interface. This is not necessarily a person seeking a physical tourist experience or preparing for a vacation. This is the armchair, desk chair, coffee house traveler, the remote access visitor who seeks an educational and well-rounded experience of tourism on her own terms and on her own time. Virtual tourists represent many age groups and require a diversity of interfaces to obtain their ideal experience including immersive websites and more interactive devices like social media. The virtual tourist is also a cultural heritage tourist, and in a difficult economic climate, when institutions of cultural heritage are fighting harder than ever for market share, cultural heritage institutions must court this visitor. ${ }^{2}$

1. The Thomas Jefferson Foundation, "Monticello Explorer," Monticello http://www. explorer.monticello.org (accessed January 15, 2012). The experience described is available in the "Monticello Explorer" on the "General House Tour."

2. Scholars of marketing, tourism, and cultural heritage tourism have been exploring the virtual tourist and experiences that create virtual tourism for over a decade. For an introduction to this conversation see: Jean-Michel Dewailley, "Sustainable tourist space: From reality to virtual reality?” Tourism Geographies 1, no. 1 (1999): 41-55; Yu-Chih Huang, Sheila J. Backman, Kenneth F. Backman, and DeWayne Moore, "Exploring user acceptance of 3D Virtual Worlds in Travel and Tourism Marketing," Tourism Management (2012) http://dx.doi.org/10.1016/j. 
Virtual interaction does have its limits. Virtual tourists do not have the tangible experience of the physical location to draw on, they have a limited ability to ask questions of staff, and are more likely to develop their own interaction with material rather than following the more emphatically suggested order available at the physical institution. For example, a suggested or enforced progression of interpretive film, residence tour, grounds tour, museum, gift shop at a physical site is much more difficult to control online without alienating those visitors seeking exploration and freedom in the virtual environment. The virtual tourist is not forced to interact with difficult history or any narrative that they find less interesting or relevant because they are in control of their content interactions. Finally, institutions that support a virtual tourism audience may find themselves expending precious funds to court an audience that takes for granted that online access will be free because fee-based interactions are not standard for this audience. However, through virtual interactions, heritage institutions have the ability to reach more visitors and potential donors more frequently and provide accessible experiences for those who cannot easily travel to or engage in tours of heritage locations. The virtual tourist audience is a significant factor to consider in the future of heritage interactions and should be of equal concern in the development of mission and available content on-site and off-site. ${ }^{3}$

The study of cultural heritage tourism represents an interdisciplinary mix. Those who study the subject frequently draw upon theories from tourism, marketing, public history, sociology, and psychology to analyze the delicate balance that heritage sites seek among their interests in education, market share, funding, and visitor numbers. These issues come together to some degree at all heritage tourism locations, but where their impact is most recognizable is at the web presence of these institutions. This issue goes beyond simple marketing and visitor numbers. The web presence has become an essential element of the guest interface. Heritage tourism destinations must embrace the web presence and social media outlets that a new generation of visitors demand and respect as measures of relevance. An effective web presence is the gateway to heritage tourism for a new generation, cultivating new audiences, new media, and expanding existing visitor relationships.

Although the use of Web 2.0 platforms by heritage tourism institutions is not new, it is also not universal. The concept of a virtual tourism experience made most possible by Web 2.0 platforms and social media interaction is the focus of this study. Immersive and interactive web content is not the only

tourman.2012.09.009; David C. Wyld, “The Virtual Tourist: Using the Virtual World to Promote the Real One," Advances in Competitiveness Research 18, no. 1\&2 (2010): 111-120.

3. A more detailed discussion of the paradoxical elements of the virtual museum environment is found in Lianne McTavish, "Visiting the Virtual Museum: Art and Experience Online" in New Museum Theory and Practice, An Introduction, ed. Janet Marstine (Oxford: Blackwell Publishing, 2006), 226-43. Consideration of the positive and potentially problematic issues related to web audience and archives can be found in Kate Theimer, ed., A Different Kind of Web: New Connections Between Archives and Our Users (Chicago: Society of American Archivists, 2011). 
technology being employed by American heritage institutions, but it is the most accessible to the widest range of audiences and therefore has the potential for greatest impact on virtual tourists. Many institutions have already embraced this trend, developing educationally based and immersive experiences for virtual tourists. The web experiences at Mount Vernon, Colonial Williamsburg, and Monticello provide instructive examples of how institutions approach this issue and court a new generation of donors and visitors in a virtual context. ${ }^{4}$

Some institutions use web content only out of necessity. Recognizing that guests increasingly look for a website when planning their excursions, some heritage tourism locations have incorporated websites as a way to put a digital footprint on the web. These web entries include the days and hours of operation, and some tour information, but overall, their websites are like a virtual pamphlet. The analogy to a pamphlet is useful. Even as recently as ten years ago, guests would seek pamphlets at hotels and visitor centers to direct their experience at a certain location. The American Automobile Association (AAA) tour book was also a valuable resource for both heritage institutions and heritage tourists, providing both valuable information and advertising space. However, as technology has changed so have the expectations of guests. Not only are traditional tour books and paper maps no longer the vacation essential they used to be for the well planned traveler, but modern heritage tourists are looking for different kinds of information in a website. More than an online pamphlet, they expect a website that not only gives directions and times, but also previews the experience, sells the physical location, and encourages them to find out more. If a website is unimpressive, they wonder, will the physical location be similarly lackluster? Scholars of tourism and

4. There are many exciting avenues to explore with regard to expanding guest experience through new technology. The one that is most discussed recently is the potential and future of mobile applications. I see a distinction between the mobile app user and the virtual tourist. The mobile app user is likely already a visitor to a location or the app would not be useful. Many mobile apps are tailored only for the physical visitor with little real content for the virtual tourist audience who may never step foot on the grounds of the institution. There are a number of mobile applications that seek to enrich the experience of the tourist who is engaging in a physical and more traditional interaction with the aid of a mobile application for orientation, education, or entertainment. A good example is the National Park Service National Mall and Memorial Parks application available both on Google Play and in the App Store. This application allows the visitor to obtain basic information about the park, daily schedules, geo-positioned maps to facilitate touring, the ability to create a custom postcard with the camera on their device, and a "Park Lens" which creates "augmented reality" through the device camera adding labels and information to the monuments in view. If a guest in not at the National Mall or in the Memorial Parks this application does not offer the same level of dimensional content. The issue of the hybrid tourist seeking this smart device assisted experience is an interesting one but not a topic for this study. In addition to the concerns listed above I have also selected not to include mobile apps for reasons of access. While the smart phone and tablet app is an exciting technology they are only available to those who have mobile smart devices. Virtual tourism is more widely accessible I would argue due to the prevalence of web services at low or no cost in public libraries across the country and in the homes of many Americans. It should also be noted that none of the subject institutions in this work, Monticello, Mount Vernon, or Colonial Williamsburg, have an available mobile application currently. 
marketing writing about virtual community and internet marketing at tourist destinations have made it clear that online interactions including virtual experiences and social media have an impact on tourist behavior and the likelihood that a visit will occur. These studies also consider the development of online communities facilitated by websites such as TripAdvisor and their role in determining tourist behavior. ${ }^{5}$ For a heritage tourism institution, then, there are choices to be made. Is the website for basic information? Is it a tool for advertising? Is it to create positive customer relationships and loyalty to the brand? Is it a forum where guests can engage in an educational experience? A well-conceived web experience can do more than develop a digital footprint. It can provide a venue for learning, exploration, and repeated visitorship. The extent to which the goals and mission of the online experience mirror those in place for a physical location affect whether it will keep guests returning, as well as continued investment in the institution, emotionally, intellectually, and hopefully monetarily.

Heritage tourism locations are not just locations of history where the public comes to learn, tourism studies suggest, but are also businesses that depend upon a customer base. This customer base must remain engaged and committed to the experience and the institution. Like any business both new customers and repeat customers are essential to success. The connection between business and public history is not always fully explored by historians because academic history does not consistently acknowledge the business aspect of the field's public practice. Economic considerations are sometimes not fully acknowledged even by public historians, despite the fact that many public historians working at public and private institutions are called upon to handle management, marketing, and other business concerns. ${ }^{6}$

5. For an introduction to the discourse of virtual tourism and marketing see: Wen-Bin Chiou, Chin-Sheng Wan, and Hsin-Yi Lee, "Virtual experience vs. brochures in the advertisement of scenic spots: How cognitive preferences and order effects influence advertising effects on consumers," Tourism Management 29, no.1 (February 2008): 146-150; Anna Maria Munar and Can-Seng Ooi, "What Social Media Tells Us About the Heritage Experience," Working Paper (Copenhagen Business School, Center for Leisure and Culture Services, Working Paper Series, 2012) http://openarchive.cbs.dk/bitstream/handle/10398/8439/Can-Seng_Ooi_WP120330.pdf? sequence $=1$ (accessed January 17, 2013); Youcheng Wang, Quaehee Yu, and Daniel R. Fesenmaier, "Defining the Virtual Tourist Community: Implications for Tourism Marketing," Tourism Management 23, (2002): 407-417; Susan Wilening and James Chung, Life Stages of the Museum Visitor: Building Engagement Over a Lifetime (Washington, D.C., American Association of Museums Press, 2009).

6. Discourse related to locations of cultural heritage and the interplay between cultural heritage management, cultural heritage tourism, business, and marketing appears in several fields including tourism, marketing, and cultural heritage management. The conversation on this topic includes issues relating to authenticity, commercialization, and impact on heritage tourists overall and is international in focus. For a consideration of the need for partnership and communication between cultural heritage managers and tourism, including methods to create better partnerships, see Bob McKercher and Hilary du Cros, Cultural Tourism: The Partnership between Tourism and Cultural Heritage Management. (New York: Routledge, 2002). Discussion of business success factors as related to cultural heritage operation can be found in Michael Hughes and Jack Carlsen, "The business of cultural heritage tourism: critical success factors," Journal of Heritage Tourism 5, no. 1 (2010): 17-32. An instructive case study on the benefits of relating 
An essential business aspect of heritage tourism has been marketing. The integration of websites into heritage tourism did not happen only in response to a need to broaden the educational experience; it was often also done as a method to improve marketing. Museum research has borne out the marketing expectation. Based upon the 2009 Life Stages of the Museum Visitor survey, for example, guests in their 30s were more likely to make decisions about visiting local attractions based on internet content and word of mouth than on other factors. Those aged in the $60 \mathrm{~s}$ and $70 \mathrm{~s}$ were more likely to make decisions based on guidebooks, printed brochures, and newspapers. As the authors pointed out, the results indicated that these printed methods may become obsolete over time. The survey results also indicated that radio and television advertisements are not a favored means for gaining information on these decisions. ${ }^{7}$

It is important to make a distinction between those websites created for basic advertising purposes and those focused primarily on broadening the educational experience and developing customer relationships. Those institutions that have developed educationally based websites are encouraging guests to consider educational content before promoting an exchange of money and product. It is certainly acceptable to market a heritage institution but the interaction with the visitor, even the virtual visitor, must be one driven by the desire to educate and encourage engagement. Consider a visit to a physical heritage location. It is rare to see the incorporation of blatant advertising for other products during the guest experience. Although guests may be encouraged to explore a gift shop or eat at a tavern, the primary purpose of the experience is to educate. If this were not the case, docents would begin and end tours with advertisements. The web experience must function in a similar manner, making historical exploration the primary focus and providing other information in a manner that is useful and functional, but does not detract from the educational narrative.

While the primary function of public history is to educate and engage the public in history, whether neighborhood stories or international narratives, this educational function can be arrived at in a number of ways at a history site's physical and virtual locations that reinforce each other and encourage an enriching experience. Education at the physical heritage location can take many forms - a tour, an exhibit, a film, a reenactment-the list is endless. The same is true of web locations. Guests who begin their interaction with the website often start the learning process there, even if this engagement is unconscious. The guests who then visit the physical location are expanding

\footnotetext{
business, marketing, and heritage tourism for future planning and to access local economic impact is found in Inhyuck "Steve" Ha and Sandra S. Grunwell, "The Economic Impact of a Heritage Tourism Attraction on a Rural Economy: The Great Smoky Mountains Railroad," Tourism Analysis 16, no. 5 (2011): 629-636. Notably, very little discussion of the relationship between history, historic resource management, and business models is found in public history discourse.
}

7. Wilkening and Chung, 39-41. 
their new knowledge through physical interaction and tactile experience. Finally, those guests who want to learn more can return to the website later, to consider what they have learned. The web component can be a significant tool in creating a positive and effective learning environment in heritage tourism.

With concerns such as donation, visitation, and activism, as well as education, heritage institutions must consider their goals and mission when making key decisions about interaction between physical and online presence. To develop a unified goal and mission in which each element contributes to an overall understanding of the concepts presented, there must be harmony between the two. Interpretive planning, with invested community partners and organization members, need not be restricted to interpretation of the physical site. Indeed, the process of analysis and evaluation involved in developing a physical site interpretive plan can be very useful in considering web content and how that content should function in relation to both physical and web-only patrons. ${ }^{8}$ Many institutions already operate under an interpretive plan that considers interpretation of tangible resources and the physical location. The approach suggested in this article encourages planners to think in encompassing, integrative terms, including websites and social media as tools of the interpretive process.

There has been extensive conversation within this journal and in the field of public history generally about a crisis in visitor numbers and perceived relevance. ${ }^{9}$ The answer to the questions and concerns posed by historians about visitor numbers, the evolution of the location-based heritage experience, and continued relevance can be answered through thoughtful implementation of online programming and social media with an interpretive focus. Historian Benjamin Filene argues that history museums are losing touch with audiences because of the impersonal nature of the historical experience developed by "insiders," those who are professionally trained to

8. A good basic discussion of the process of interpretive planning can be found in Barbara Abramoff Levy, "Interpretation Planning: 'Why and How," in Interpreting Historic House Museums, ed. Jessica Foy Donnelly (Walnut Creek: Alta Mira Press, 2002), 43-60.

9. These two issues, the crisis in visitation and the problems of perceived relevance, have been covered extensively in this journal. Recent marketing studies conducted by the United States Department of Commerce and the United States Cultural \& Heritage Tourism Marketing Alliance have pointed to slightly different considerations with regard to these issues, namely that the manner in which Cultural Heritage Tourists define a "cultural heritage tourism experience" has undergone significant change. An experience of cultural tourism can be loosely defined as anything perceived as involving culture, even staying at a bed and breakfast or going to an antique store. However, while the definition has changed, the demographic makeup of the core cultural heritage traveler has not. More information can be found in: U.S. Department of Commerce, "Office of Tourism and Travel Industries 2010 Cultural Heritage Traveler," http://www.tinet.ita. doc.gov/outreachpages/download_data_table/2010-cultural-heritage-profile.pdf (accessed August 8, 2012); Rosemary McCormick, The Cultural and Heritage Traveler Study: A White Paper From Mandala Research, Shop America Alliance, and the U.S. Cultural \& Heritage Tourism Marketing Council (Mandala Research, 2010) http://www.uscht.com/content/Cultural\% 20\&\%20Heritage \%20Traveler\%20Research\%20White\%20Paper\%20MSA-WP7.pdf (accessed August 8, 2012). 
engage in the interpretation and business of history. Meanwhile "outsiders," individuals that he identifies as those working outside of traditional institutions, without the benefit of formal training, and without access to traditional funding sources, are having more impact with the public and generating more "buzz" about history. Filene suggests a change in the manner of curriculum at public history degree granting institutions in order for "insiders" to adopt an "outsider" perspective, one that is more personal and focused on themes that create emotional connection to the past. Anne Ackerson, director of the Museum Association of New York, argued in a 2011 article that recent trends in history museums, particularly local history institutions, have been focused on scarcity thinking. Scarcity thinking, based on her analysis, does not seek to expand interpretation or interaction with the community because of budgetary concerns. She encourages history museums to deal with dropping visitor numbers by engaging in abundance thinking, considering social media, partnership, and community engagement as problem solving techniques. Ackerson suggests that public historians should be the driving force of change in these institutions. Both Ackerson and Filene highlight the pressing issue of dropping visitation numbers at history institutions and both see social media as a strong component of the solution. This is an important connection but it can be pushed further. An improved overall web presence and more meaningful implementation of social media can be the first step toward improving visitor interaction and engagement, leading to physical visitation or fee-based web experiences like virtual field trips. ${ }^{10}$

Scholars of tourism and marketing can usefully contribute to conversations about the appropriate use of web content and creating a positive business model for public history institutions. The use of the web as an effective marketing tool and the sometimes delicate balance between presenting good history and providing a marketable tourism experience is a continuing conversation within both the history and hospitality fields. Several articles and monographs on this topic have been published in the last ten years. These studies are concerned with characterizing and considering the needs of the museum visitor. Although some of these studies are historical in nature, many others take a sociological perspective to this interesting puzzle. Ackerson's work discusses a number of recent studies on visitor numbers, future visitor needs, and museums. The most well known of these has been published as Life Stages of the Museum Visitor: Building Engagement Over a Lifetime. This work brings together studies over several sectors and comes to conclusions about the best way to reach various generations of museum visitors in the present and in the future. The Life Stages study posits that as museums move forward they must understand that museum visitors are changing, that

10. Benjamin Filene, “Passionate Histories: 'Outsider' History-Makers and What They Teach Us,” The Public Historian 34, no.1 (Winter, 2012): 11-33; Anne W. Ackerson, “The History Museum in New York State: A Growing Sector based on Scarcity Thinking," The Public Historian 33, no. 3 (Summer, 2011): 18-37. 
they interact with information in different ways, and that they are seeking complex experiences. Complex experiences that rethink narrative, that respond to a need for authenticity, and that expand educational access points can be created in a new more responsive and thoughtful web presence. The 2012 National Arts Index, which studies arts and culture in the United States, makes several instructive points to this effect. First, that while we see dropping numbers in physical visitors to arts and cultural institutions we have not seen an overall drop in art and culture consumers. The authors posit that consumers are instead interfacing with arts and culture in "ever expanding ways" and "walking away from some traditional modes of delivery." The National Arts Index also argues that technology is having increasingly significant effects on consumer activity and that "Savvy nonprofit arts organizations are using technology to broaden their audience base and enrich the audience experience." As professionals that serve this public audience, we would do well to heed the findings of these studies. The virtual tourist audience is a large part of this expanding audience base and interested in new methods for the consumption of cultural and heritage product. ${ }^{11}$

Finally, public historians who are engaging in new museum theory provide the last piece of the theoretical puzzle when considering a nuanced webbased museum experience. Studies in new museum theory about transparency in exhibit design, engagement with guests, and the connections between public memory and the museum experience can be instructive in considering the larger implications of physical and virtual synthesis in heritage tourism. Although this discourse has not fully considered the unique needs of the heritage tourism experience, including that of crafting memory and creating historical engagement, many of these practices have been incorporated into history museums. Historians of memory and technology have explored the potential of web-based museum environments and their ability to create unique and problem-solving installations. For example, historians Michael O'Malley and Roy Rosenzweig, within a larger article considering the positives and negatives of web-based history, explore the possibilities of web reconstruction for historic resources that no longer remain, allowing guests to explore what they could never experience in person. Additionally, they consider the application of web-based resources in conjunction with exhibits to permit guests a greater measure of time and depth than can be obtained within the constraints of a physical gallery. More recently, Cary Carson has argued, based on surveys conducted at historical institutions such as Connor's Prairie and Colonial Williamsburg, that guests want to feel like they are part of something larger than themselves and be part of a new way of experiencing history. Carson specifically points to the potential for online experience,

11. John K. Falk, Identity and the Museum Visitor Experience (Walnut Creek, CA: Left Coast Press, 2009); Wilkening and Chung, 141-51; Roland J. Kushner and Randy Cohen, National Arts Index 2012: An Annual Measure of Arts and Culture in the United States: 1998-2010 (Americans for the Arts, 2012), 13 http://www.artsindexusa.org/wp-content/themes/ AFTA\%20for\%20WP/doc/2012-NAI-Full-Report.pdf (Accessed January 21, 2012). 
mobile applications, and coordinated experiences linked through webassisted technology to improve relevancy and guest interaction. The findings from the Arts Index study indicate the same trend; Americans seek a personal experience within their cultural experience. ${ }^{12}$

These conversations are intimately related. The studies by Ackerman, Filene, and the recent visitor studies all indicate the same issue- the museum visitor is changing. Expectations are in flux. Visitor numbers are dropping at history institutions as potential visitors are looking for new kinds of interface with the past. They are looking for readily available information, sometimes in small pieces that have personal resonance. When Filene sees history "outsiders" as attentive to these means of interaction with the past he reminds us that it is only the professionalization of public history that has created an insular "inside" that could learn from attention to the ideas of "outsiders." Public history has always been interdisciplinary and benefitted from the views and creative ideas of many individuals. That it is people who are "outsiders" who seem to be most responsive to the new nature of history's audience is further evidence of a phenomenon that public historians have warned of since the mid-1990s, that academic public history is losing touch with the realities of public history practice. I consider the drop in visitor numbers as related to this rift. It can be bridged, as comparison of web practices the three institutions I examine suggests, when public historians open themselves to this new visitor set and engage in the types of web-based experiences suggested by O'Malley, Rosenzweig, and others that encourage greater learning outside the confines of physical space. Social media and web content are key elements of this work to reach out to the visitor and provide them with the types of experiences that they are seeking. This must be done with the visitor in mind and should borrow techniques from those supposed "outsiders" who are finding success in courting visitors, donors, and public engagement. For history institutions, the first step is considering these elements as central to the interpretive message, governed by the same mission, goals, and interpretive focus as the physical locations that they administer and with the same potential to advance institutional goals.

Many heritage tourism institutions use their websites effectively and most have integrated some type of social media into their experience. Many send emails to keep visitors, donors, and friends up to date on larger happenings, but social media increasingly has become an important tool. The blog or RSS feed, Facebook page and Twitter account have become the basic social media toolkit useful for public historians to court visitors and cultivate future activists and donors. Social media allows for short updates allowing someone to feel connected to an institution without visiting or the larger commitment of

12. Michael O'Malley and Roy Rosenzweig, "Brave New World or Blind Alley? American History on the World Wide Web" The Journal of American History 84, no. 1 (Jun 1997): 17-25; Cary Carson, “The End of History Museums: What's Plan B?” The Public Historian 30, no. 4 (Fall 2008): 9-27; Kushner and Cohen, 13. 
reading a newsletter. Social media can also keep guests interested, inspiring future visits and encouraging educational exploration. A tweet about a new exhibit, for example, can lead to something larger, a conversation about controversial topics, sharing of personal experiences with regard to the subject, maybe even a historically-based flash mob. There is little need in a modern media environment for educational interaction to be confined to a physical location or to the time period of the visit itself. Considering online and social media tools as a gateway to a more encompassing educational environment alters the manner in which interpreters can consider message, evidence, and overall goals. These tactics are successfully employed in other arenas of entertainment, why not the arenas of edu-tainment and heritage tourism? Heritage locations compete, consciously or not, for visitors with other types of experiences such as amusement parks. It should not be considered inconsistent to market in a similar fashion, with the added benefit that this marketing has an educational component and mission.

When considering the overall approach to developing virtual content of any kind, whether web interface, virtual exhibit work, or podcasting, public historians must pay careful attention to narrative. Sites must develop a single overarching narrative that reflects the everyday life of the interpreted period and includes multiple voices of active historical participants. A cohesive narrative, appropriate to interpretation at both the physical and virtual sites, is imperative to develop a strong educational experience. This approach focuses the message, reflects a diverse perspective, and involves those elements of historic locations that, based on recent studies, visitors find most engaginga personal interaction with the past that resonates with their experiences and yet reflects enough difference from their experiences to inspire reflection. Experience suggests that this type of educational experience cannot be gained through disjoined physical and online interaction. In order to achieve the highest educational value and positive, lasting guest relationships, an institution's interpretive narrative must be strongly and consistently implemented for both the physical and virtual guest interface. ${ }^{13}$

Without a unified narrative, institutions fall into the trap of creating segregated narratives, interpretive narratives that have been removed from the overall goal or mission and therefore appear less important to guests. Developing web-only content that does not have an interface or reference point at the physical location creates an instantly segregated narrative. A location that does not deal with the contributions of women in their primary tour or in special topics installations on-site, but includes extensive treatment of these issues on the website, has created a segregated narrative. Guests are given the immediate impression that this history is less significant. If it were truly important, the docent would have mentioned it. It would have been visible and evident at the physical location. In addition, those guests who have thoroughly explored the web experience may come to the physical location

13. Kushner and Cohen, 13. 
with topical expectations based on the virtual material presented, such as slavery or warfare. When these expectations are not met, for example topics that were on the website do not interrelate well with the physical experience, it creates confusion, and in the end, lessens the experience for the guest and damages the guest's relationship with the institution. ${ }^{14}$

The issue of unified narrative leads to another concern. Is it possible to create a mixed experience that integrates both the physical and virtual site well? Will one always be subordinate to the other? It is possible to create content that blends the two successfully while creating an accurate and challenging narrative but it takes careful consideration by designers at many levels. The key is that the institution and its interpreters must, from the first, make a commitment to presenting an accurate narrative that is true to the overall interpretive mission. Once this commitment is established it must be implemented both at the physical location and in virtual exhibits or web design. Both must present the same basic narrative but approach the issue in a different manner in order to avoid exact repetition and to encourage educational exploration. For example, the physical location, with the assistance of a docent, can encourage guests to think about the narrative through the use of architecture and artifacts. The virtual exhibit content can then present the same narrative and ask guests to think about it differently, maybe to put themselves within a certain time or place interacting with an artifact, or encourage them to engage with documents related to the artifact. There are many possibilities in this interaction that will not only encourage more depth in the educational experience but also continue the guest relationship with the institution after the physical visit has ended. New ideas can be introduced, leading guests to think in larger terms or in different ways. It is not inconsistent for the website to expand on previous themes, but the themes must be presented in context first and in reference to the overall narrative. For example, if a docent discusses the place of servants within the household on the physical tour, the virtual component can encourage guests to learn more about servants and the running of households. This is not the creation of a separate narrative; this is the creation of a challenging and exciting educational experience for guests and an extension of the physical experience.

The following analysis of some current websites and their work to create lasting and positive guest relationships illustrates how web content can create an immersive educational experience either in lieu of or in conjunction with physical visits to a public history institution. The subject websites are attached

14. For a more thorough discussion of the phenomena of creating separate narratives with relation to women's history or African American history see Patricia West "Uncovering and Interpreting Women's History at Historic House Museums," in Restoring Women's History Through Historic Preservation, ed. Gail Lee Dubrow and Jennifer Goodman (Balitmore, MD: Johns Hopkins University Press, 2003), 83-95; Jennifer L Eichstedt and Stephen Small, Representations of Slavery: Race and Ideology in Southern Plantation Museums (Washington: Smithsonian Institution Press, 2002); Jennifer Pustz, Voices from the Back Stairs: Interpreting Servants' Lives at Historic House Museums (DeKalb, Northern Illinois University Press, 2010). 
to physical locations with relatively high visitor numbers that are recognizable to the general public: Mount Vernon, home of George Washington, Colonial Williamsburg, an outdoor living history museum, and Monticello, home of Thomas Jefferson. All three of these institutions are located in Virginia and all three have experienced the crisis of visitor numbers reported across the United States by heritage institutions. I examine both the available virtual experiences at these websites and the layout of the website. Ease of navigation, the order of presentation for content, and visual clues are important elements of web browsing. A 2008 study by Frias, Rodriguez, and Castaneda in the journal Tourism Management considered the formation of positive and negative image of tourism locations pre-visit based on travel agency visits and internet interactions. Their findings concluded that guests who were wellversed in online activity were less likely to be overwhelmed by extensive online content and that furthermore "the key to avoiding that overload lies in offering high-quality content and first-rate design." Overall, ease of use and visual appearance were found to be significant factors in educating internet users of many skill levels. Given these findings, it is clear that both content and design are crucial elements in developing online interactions for virtual tourist audiences. $^{15}$

Mount Vernon, the home of George Washington, is operated by the Mount Vernon Ladies Association (hereafter MVLA). This organization, incorporated in the nineteenth century, worked to save Washington's home from destruction. Their mission statement is clear and widely available both on the website and at the physical location: "The Mission of the Mount Vernon Ladies' Association is to preserve, restore, and manage the estate of George Washington to the highest standards and to educate visitors and people throughout the world about the life and legacies of George Washington, so that his example of character and leadership will continue to inform and inspire future generations." 16 The mission of the organization is evident throughout their interpretation at the physical location, tours of the grounds, the visitor center, associated museums, new library, and the residence itself. Analysis of the website reveals a consistent commitment to the mission statement. In addition to representing a good reflection of the mission of the organization, the website for Mount Vernon also represents a type of best practice for institutional web presence. Mountvernon.org is organized in a hierarchy with multiple tiers of information. Each tier represents a different aspect of the web experience and includes many opportunities for visitor interaction. The organization is intuitive, with the information most relevant to potential web visitors closer to the top of the page. The navigation bar for

15. Dolores Ma. Frias, Miguel A. Rodriguez, and J. Alberto Castaneda, "Internet vs. Travel Agencies on Pre-Visit Destination Image Formation: An Information Processing View," Tourism Management 29, no. 1 (February 2008): 163-179.

16. Mount Vernon Ladies Association, “About Mount Vernon: Our Mission," George Washington’s Mount Vernon Estate, Museum, and Gardens, http://www.mountvernon.org/visithis-estate/general-information/about-us (accessed July 10, 2012). 
the website is black with white script but three buttons stand out in red: "Meet George Washington," "Visit His Estate," and "Support His Vision." From the first it is possible to see the three goals of this website, "Meet George Washington" relates to history education, "Visit His Estate" speaks to tourism, and "Support His Vision" is related to donor activity. As online guests scroll down, the tiers of information reinforce these three goals.

The tiers of information at MountVernon.org consider the visitor's needs and reinforce the multiple platforms available for education at the physical location and within the virtual experience. There is choice, engagement, and a subtle encouragement for guests to explore, either at the physical location or through the web interface. In the first tier the focus is on the physical location itself and information for those planning a trip. This includes events, available tours and experiences, and tools to plan a visit. In the second tier the website is focused on education. In this area guests can view an online library, a series of online exhibits, and learn about special topics. In this second tier the mission of the MVLA is clear; they are focused entirely on Washington and all aspects of his life. In the third tier guests interact with the financial aspects of Mount Vernon. They can purchase tickets, learn about shopping and dining, additional available experiences, and become Mount Vernon donors. At the bottom of the page are connections to social media like Facebook and Twitter, resources for educators, and customer service links. Not only has MountVernon.org created a good reflection of the physical location experience under a unified mission, it has created in the mind of the user a hierarchy of the focus of the online presence. The website is focused on guest experiences, guest education, and eventually, guest money. This is clearly the website of a learning-based business that has maintained a focus on the educational aspects of the institution. ${ }^{17}$

Colonial Williamsburg in Williamsburg, Virginia is a living history installation and museum complex operated by the Colonial Williamsburg Foundation. It was constructed and reconstructed in the 1930s from the remains of old Williamsburg, Virginia’s colonial capital, by John D. Rockefeller, Jr. Colonial Williamsburg has worked to maintain a healthy business model and redefined itself continually through the past eighty years to accomplish this goal. They not only offer educational content but also have added numerous hotels and resort amenities to create a total experience for guests. A strength of the Colonial Williamsburg Foundation is that throughout its history it has worked, with varying degrees of success, to respond to the interests and needs of the guest population. With this goal in mind, the potentially controversial topic of slavery has been added and removed and added again, the interpretation of the overall streetscape has changed, and recently, eighteenth-century Cherokee presence in the colonial city has been added to interpretation. Their mission

17. Mount Vernon Ladies Association, "George Washington's Mount Vernon Museum, Estate, and Gardens,” George Washington’s Mount Vernon Estate, Museum, and Gardens, http://www.mountvernon.org/ (accessed July 10, 2012). 
statement is simple and concise: "That the future may learn from the past." Although this may seem unfocused it perfectly describes the interaction between the web presence and the physical institution constructed by Colonial Williamsburg. Both clearly have education as their primary focus with a good understanding that audience and modes of interaction are constantly changing. ${ }^{18}$

Colonial Williamsburg operates five websites, and all are linked, but each maintains a separate web address. This allows for a clear separation between the elements of the website. Educational content is primarily contained on the principal website, history.org. The financially based website, colonialwilliamsburg.com, is linked to history.org, but not a primary focus. It is not possible, for example, to determine the cost of admission on history.org. The five websites are linked with a tool bar that appears on each page listing the headings "Visit," "Learn," "About Us," "Donate," and "Shop." If these headings reflect a hierarchy of goals, then the website is seeking physical visitors first followed by encouraging education. These interests are also clear in the organization of the history.org page.

The history.org website is tiered in presentation of information. The first tier is entitled "What's New Online" and includes a rotating series of new experiences for online guests. This includes podcasts, recipes, blogs, and multimedia programming of many types on any given visit. Not only is history.org focused on education, it acknowledges through this presentation that the online visitor can actively participate in the Colonial Williamsburg experience and benefit from the mission of the Foundation no matter their physical location. It works to create the elusive personal experience of the past in an online format. By focusing the first tier on accommodating the online guest, the website underscores that exclusively virtual visitation is not only acceptable, but that it is fully supported and not considered subordinate to the physical site visit. Indeed it is the second tier that is concerned with planning a physical visit. Links are provided to the colonialwilliamsburg.com page for concerns such as accommodations and ticketing. Special upcoming events are also listed in this area, such as "Cherokee Week," July 18-22, 2012. The "Tour the Town Feature" allow guests to view a map of available experiences and the buildings within the historic area. The third tier of the website includes multimedia and social media. There are many types of interactive content and functions that are appealing to Generation Y users, as identified by studies such as Life Stages. Guests can use webcams, watch video, link to Facebook and Twitter, read the blogs and journals, and watch webcasts. This is an ultimate expression of using the future to explore the past. ${ }^{19}$

Thomas Jefferson's home, Monticello, is an institution working to create dialogue and engagement with guests through web and social media content.

18. Colonial Williamsburg Foundation, "About Us: Mission of the Colonial Williamsburg Foundation," Colonial Williamsburg, http://www.history.org/foundation/mission.cfm (accessed July 11, 2012)

19. Colonial Williamsburg Foundation, "Colonial Williamsburg: Home Page," Colonial Williamsburg, http://www.history.org/ (accessed July 11, 2012). 
Monticello is operated by The Thomas Jefferson Foundation. The Foundation abides by a two-fold mission of preservation and education. In addition to their published mission statement, the Thomas Jefferson Foundation also includes a published statement of vision on Monticello.org which includes the following sentiment: "Through virtual, off-site and on-site engagement, the Foundation seeks to excite the world about Jefferson's relevance today and ignite a passion for history." ${ }^{20}$ This statement of vision is consistent with the needs of a new generation and acknowledges that guests will interact with the institution through multiple platforms, at the physical location itself, and through its virtual content.

The main Monticello.org page is organized in three vertical columns topped by a single horizontal bar that rotates featured attractions at the physical site and a horizontal bar at the bottom of the page that includes online offerings. At the very top of the page a tool bar provides a series of navigation options including, in order from left to right, "Visit," "Jefferson," "House \& Gardens," "Plantation \& Slavery," "Research \& Collections," "Families \& Teachers," "Donate," "Shop," and "Online Community." Monticello .org provides more navigation options in the toolbar than the other two websites considered. Consistent with other websites "Visit" is an early entry, indicating either the preference for guests to visit or an acknowledgement that many will navigate to the Monticello.org website because they are planning a visit. The horizontal feature bar rotates between experiences available at the physical site but does not include experiences available solely for the virtual tourist. The three vertical columns are entitled "Plan Your Visit," "Highlights," and "Community." Both the "Plan Your Visit" and "Highlights" section are concerned with experiences available for physical visitors to Monticello. "Plan Your Visit" details the "nuts and bolts" of a visit to Monticello such as ticket price, driving directions, and upcoming events. The "Highlights" section details tour options and ticket bundles. "Community" is a section for interaction with the Monticello Online Community, which guests can enroll in and follow on popular social media platforms such as Facebook, Twitter, You Tube, or Flickr. A box at the bottom of the page details "Online Highlights" and includes activities such as "Jefferson Today" which includes instances of Jefferson in the news, the "Monticello Classroom" and "Exploring Monticello: Guide for Young Learners" section which includes content for educators and children, and the "Monticello Explorer" a portal for virtual tourists to explore the residence and grounds through virtual tours, interactive maps, and 3D models, the experience that Jane, our model virtual tourist, experienced in the introduction.

Monticello.org is consistent with The Thomas Jefferson Foundation's vision of off-site engagement, but it is not fully engaged with the virtual tourist. The social media platforms available provide information for

20. The Thomas Jefferson Foundation, “Mission Statement," Monticello, http://www.monticello.org/site/about/mission-statement (accessed July 21, 2012). 
educational purposes and the development of a social community, but the website gives the impression that the only true Monticello experience is the one had "on the mountaintop." This is particularly unfortunate because the content available in the "Monticello Explorer" section provides a very good virtual tourism experience. The guided tour is dynamic and includes primary sources such as documents and photographs that would not be available at the physical location. Virtual visitors also have the opportunity to join other tours or listen to podcasts with professionals about the site and the work done there. It is an opportunity for virtual guests to understand not only the institution that they visit but to break the fourth wall and understand the work of professionals to create this experience for both physical and virtual guests. However, the description of the "Monticello Explorer" on the home page does not fully convey the depth of content available and its placement at the bottom of the page makes it less noticeable to a casual observer.

The approach of Monticello.org does much less to develop a base of virtual tourists than do the websites of Mount Vernon or Colonial Williamsburg. To term this interaction with a virtual public "off-site" engagement divorces it from the physical on-site experience and defines it as outside of the physical parameters of the institution. Although the phraseology may only be rooted in geographical presence, the implication is that the web experience is removed from and less valuable than the physical tourist experience. The off-site engagement of Monticello.org through social media is focused on furthering an intellectual conversation about the Foundation's goals-engagement with history and interaction with Jefferson and his legacy. It does not provide as expansive a forum for learning by doing, exploration, online exhibits, or some of the more creative endeavors that other institutions are embracing. Monticello.org emphasizes thoughts and words, but is less focused on actions and offers fewer chances to engage with the site's tangible offerings from outside of the walls of the physical institution. The "Monticello Explorer" contains good content and has the potential to create a customer relationship and inspire brand loyalty, but does little more than that. For those looking for an experience that is fully different from the on-site experience or provides creative approaches allowing them to experience personal association with the material, the virtual offerings at Monticello will not satisfy fully. This approach courts the demographically traditional museum visitor as outlined by several surveys on cultural tourism and economic impact. It does not seek to court a new generation or a virtual tourism base with the same enthusiasm.

All three websites do offer depth of content. It is clear that these are well supported, constantly changing, and actively interpreted experiences. There are literally hours of content available on these websites. Every click produces trees of other related websites and experiences. The depth of content encourages extended exploration, which can only lead to positive results for the institutions. Those who spend time on the website and are engaged may become return visitors, make a physical visit, or become donors. Investment in an educational, immersive, and entertaining web experience that is 
consistent with the mission statement and the needs of a new generation of users will pay in dividends over time.

Each institution also offers multiple platforms for social media interaction at different levels. Although Facebook and Twitter are prominent among them, they are not the only offerings. Tumblr, Flickr, Pinterest, Instagram, and YouTube allow for guests to engage in many levels and experiences. For the very engaged social media user, Tumblr, Twitter, and Facebook are great forums to participate in conversations beyond the simple update. They can allow for polls, contests, and engagement for local and international visitors alike. Flickr and Instragram, both photo blog programs, allow followers to see beyond the publicity photos of an institution and experience the physical site through the eyes of other guests or employees. The voyeuristic appeal of these programs operate much like the word of mouth publicity that might be found on a platform like Facebook or Pinterest. The YouTube channels for the subject institutions offer visitors a behind the scenes look at the inner workings of the institution, its programming, and professionals. These social media platforms will appeal to users at varying generational and engagement levels, but each does its part to perpetuate consistent guest engagement with the institution over time. Perhaps more than any other levels of virtual interaction, social media platforms give guests a sense of the "nuts and bolts" at the institutions that they visit. As they interact with yearly programming, guest speakers, employees, and other visitors, the hidden side of heritage institutions comes to light. These behind the scenes glimpses are not only informative about content, construction, and restoration; they help guests to see the investment in research and manpower that each institution makes. This allows guests to see where their money is used and may assist in inspiring donor activity in the future.

In all historic sites, but especially those less globally prominent than Mt. Vernon, Monticello, and Williamsburg, consideration of the local community is an essential component of creating balance in virtual and physical experience. Many heritage tourists are local residents. They seek heritage tourism locations to assist them in understanding their local community, to provide educational content for children, or to occupy out-of-town visitors. The heritage tourist experience need not cater exclusively to foreign or out of state tourists. This is particularly true for web content. Although some web and physical sites focus only on out of town guests, many seek to relate to their local community to create community support for the institution and the heritage of the area. For example, Pennsbury Manor in Pennsylvania includes content on their website for out of town guests, local school groups, and local residents who are interested in their heritage. They seek to bring communities together through activities such as genealogy workshops. The Wilton House in Richmond, Virginia operates in a similar manner, advertising content on their website that encourages community participation at the physical location. They host teas, have lectures, and develop programming to reach out to young and old in their community. Neither online presence has the depth 
experienced at the larger websites, but they are employing similar tactics to engage with the virtual public with success. Although they may have operated well on their own in the physical location, the addition of a web component to teach new skills, encourage exploration, and invite community participation has enriched the visitor experience. Social media is also an important component to inspiring local investment and activism and both institutions have incorporated these tools as well. ${ }^{21}$

The issue of developing compelling mixed content also can affect donor activity. Donors are an essential component of the funding of many heritage institutions. Finding donors and retaining consistent giving is a concern to many institutional administrators. Allowing a lapse in the advancement of the website can change the relationship of donors with the institution. If donors do not feel that the institution is still doing positive work, or that they are behind expectations for heritage institutions, support may be shifted to other, more progressive institutions that are taking charge of new technology. Cultivation of donors need not begin at retirement age. A positive customer relationship can begin at a young age and evolve over time provided that the institution remain consistent in retaining relevance, value, and new experiences that appeal to many audiences. A healthy presence in social media, attention to the changing needs of guests, acknowledgement of physical and virtual audiences as equal participants, and consideration of the generational interests of guests will foster this engagement.

Colonial Williamsburg, Mount Vernon, and Monticello are all large and well-funded institutions, but small and underfunded institutions also can expand their horizons through virtual content and develop a new relationship with their communities and cultural tourists as a whole. It is true that Web 2.0 technology is costly and requires planning and maintenance. Still, even less well-funded websites can be restructured to ensure engagement with the virtual tourist community. ${ }^{22}$ My proposals do not seek to advance technology as much as to attune our use of technology to the engagement of our expanding visitor base of virtual tourists. The virtual community, whether virtual tourists, students, donors, or community members, is a valuable asset in the fight for survival of historical tourist experiences. Embracing existing technology, online activity, unified mission and educational goals, and social media can increase our historical institutions' perceived relevance to our audience, including virtual tourists. In addition to these benefits, it can foster positive relationships with visitors as customers, a proven economic multiplier.

21. The Pennsylvania Historical and Museum Commission and The Pennsbury Society, "Pennsbury Manor" Pennsbury Manor, http://www.pennsburymanor.org/ (accessed July 11, 2012); The National Society of the Colonial Dames American in the Commonwealth of Virginia, "Welcome to Wilton House," Wilton House, http:/www.wiltonhousemuseum.org/index.html (accessed July 11, 2012).

22. Consideration of the costs of Web 2.0 to institutions can be found in Randall C. Jimerson "Archives 101 in a 2.0 World: The Continuing Need for Parallel Systems" in A Different Kind of Web: New Connections Between Archives and Our Users, ed. Kate Theimer (Chicago: Society of American Archivists, 2011), 304-14. 
Creating a more meaningful web experience and embracing the virtual tourist and online community is not only good educational outreach and good business, it is good for the changing face of public history.

ANNE LINDSAY is an assistant professor of history at the University of Central Florida where she teaches courses in colonial American history and public history, including cultural heritage tourism and historic preservation. Her academic research considers the work of public historians to shape public memory at heritage sites interpreting the eighteenth century. Dr. Lindsay's professional experience is in municipal historic preservation and in preservation consulting. 